Baseline

\title{
Distribution of mercury in coastal marine sediments of China: Sources and transport
}

\author{
Mei Meng ${ }^{\mathrm{a}}$, Jian-bo Shi ${ }^{\mathrm{a}, *}$, Zhao-jun Yun ${ }^{\mathrm{a}}$, Zong-shan Zhao ${ }^{\mathrm{b}}$, Hui-juan Li $^{\mathrm{b}}$, Yu-Xiao Gu ${ }^{\mathrm{a}}$, Jun-juan Shao ${ }^{\mathrm{a}}$, \\ Bao-wei Chen ${ }^{c}$, Xiang-dong $\mathrm{Li}^{\mathrm{c}}$, Gui-bin Jiang ${ }^{\mathrm{a}}$ \\ a State Key Laboratory of Environmental Chemistry and Ecotoxicology, Research Center for Eco-Environmental Sciences, Chinese Academy of Sciences, Beijing 100085, China \\ ${ }^{\mathrm{b}}$ Key Laboratory of Marine Chemistry Theory and Technology, Ministry of Education, Ocean University of China, Qingdao 266100, China \\ ${ }^{\mathrm{c}}$ Department of Civil and Environmental Engineering, The Hong Kong Polytechnic University, Hung Hom, Kowloon, Hong Kong
}

\section{A R T I C L E I N F O}

Article history:

Available online 12 September 2014

\section{Keywords:}

Mercury

Sediment

Mapping

Transport

China Sea

\begin{abstract}
A B S T R A C T
A total of 220 surface sediments and eight sediment cores were analyzed to study the distribution and transport of $\mathrm{Hg}$ in Chinese marginal seas. Spatial distribution showed a general offshore decreasing trend towards the outer continental shelf. Vertical profiles of sediment cores displayed a general increasing trend from bottom to surface layers. Coastal land-based discharges and river-derived inputs are probably the main sources of $\mathrm{Hg}$ in coastal sediments of China seas, while TOC, $\mathrm{pH}$, ocean currents and sediment characteristics could play important roles in the transport and spatial distribution of $\mathrm{Hg}$ in sediment. The influence of TOC on Hg concentration is more significant than that of $\mathrm{pH}$. The mud deposits on the coastal shelves are main sinks of $\mathrm{Hg}$ in the region. The results showed that sedimentary $\mathrm{Hg}$ was affected by regional anthropogenic activities and riverine runoffs, and was also influenced by long-range atmospheric transport and ocean current circulations.
\end{abstract}

(c) 2014 Elsevier Ltd. All rights reserved.
Current global atmospheric deposition of mercury $(\mathrm{Hg})$ has been estimated to be three times higher than preindustrial levels (Selin et al., 2008). The anthropogenic $\mathrm{Hg}$ emission of China is the largest in the world owing to its rapid industrialization and urbanization in the last several decades, taking up approximately $30 \%$ of the global $\mathrm{Hg}$ emission (Pacyna et al., 2010; Wu et al., 2006). In the next few decades, anthropogenic $\mathrm{Hg}$ emission in China will still be likely to increase because of the continuously increasing coal consumption and nonferrous metal production (Jiang et al., 2006; Maxson, 2009; Wang et al., 2011). Unraveling the fate of anthropogenic $\mathrm{Hg}$ in the environment is an imperative and challenging task.

Coastal regions are under combined impacts of various $\mathrm{Hg}$ sources, such as river/sewage discharges and atmospheric deposition. Near-shore regions are often hotspots for the formation of methylmercury ( $\mathrm{MeHg}$ ), which is the most toxic $\mathrm{Hg}$ species (Hammerschmidt and Fitzgerald, 2004). Coastal regions thereby act as a dynamic link between the terrestrial and ocean systems, where produced $\mathrm{MeHg}$ can be easily transported to the open sea. Elevated $\mathrm{Hg}$ concentrations have been reported in mollusks and fish from Chinese coastal regions (Pan and Wang, 2012). Some

\footnotetext{
* Corresponding author. Tel./fax: +86 1062849129.

E-mail address: jbshi@rcees.ac.cn (J.-b. Shi).
}

coastal residents, fishermen and their families have been found to be at risk of elevated $\mathrm{Hg}$ exposure (Cheng et al., 2009; Fok et al., 2007). Therefore, $\mathrm{Hg}$ contamination in the coastal environment of China deserves great attention not only for the potential ecological impacts but also for the concern regarding seafood safety to human health.

Sediment plays an important role in the geochemical cycling of $\mathrm{Hg}$, serving not only as a sink but also as a secondary source of $\mathrm{Hg}$ in the aquatic environment. Sediment could receive $\mathrm{Hg}$ from both natural and anthropogenic sources. Therefore, investigating the distribution of $\mathrm{Hg}$ in coastal sediments is an effective way to understand the translocation and cycling of $\mathrm{Hg}$, and to reconstruct the chronology of anthropogenic Hg emissions at the land-ocean interface zone. Some efforts have been made to study the contamination of $\mathrm{Hg}$ in sediments from several specific estuaries and coastal regions of China, including Bohai Sea, East China Sea, Xiamen Bay, Pearl River Estuary and Hong Kong (Fang and Chen, 2010; Gu et al., 2012; Luo et al., 2010; Yan et al., 2010; Zhou et al., 2007). However, the behavior of $\mathrm{Hg}$ may differ from one estuary to another due to the various inputs, physical, chemical and hydrological conditions. The overall distribution patterns and transport of $\mathrm{Hg}$ in coastal sediments of the entire China seas have not been systematically studied and remain unclear until now.

The main objectives of this work were to assess the spatial and vertical distribution characteristics of $\mathrm{Hg}$ in coastal sediments from 
four China marginal seas, as well as to identify the possible sources and major control factors for the transport of $\mathrm{Hg}$. The results can provide essential information to better understand the transport and fate of $\mathrm{Hg}$ in coastal regions.

As a part of the western Pacific Ocean, the China Sea consists of Bohai Sea (BS), Yellow Sea (YS), East China Sea (ECS) and South China Sea (SCS). The map of the study regions and sampling locations is shown in Fig. 1. A total of 220 surface sediments were collected from the four China seas during 2011-2012, which include 29 samples from the BS, 66 from the YS, 71 from the ECS, and 54 from the SCS. The sampling sites covered most of the marginal seas except for the SCS, where all the sites were distributed within the Pearl River Estuary (PRE). Eight sediment cores were collected in April 2011, including four cores (1-4) from the central mud area of the YS and four (5-8) from the inner and central mud areas of the ECS. These sediment cores were cut into $1 \mathrm{~cm}$ intervals along the profile using a stainless steel cutter. All samples were immediately kept in a $-4{ }^{\circ} \mathrm{C}$ refrigerator after collection and thereafter transported to the laboratory where they were freeze-dried at $-45^{\circ} \mathrm{C}$ and homogenized to a fine ground powder through a sieve (80 meshes per inch).

Approximately $0.05-0.1 \mathrm{~g}$ of sediment was digested with $2 \mathrm{~mL}$ of $\mathrm{HNO}_{3}$ and $1 \mathrm{~mL}$ of $\mathrm{HCl}$ at $105^{\circ} \mathrm{C}$ for $2 \mathrm{~h}$. The concentrations of total mercury (THg) were determined with a cold vapor atomic fluorescence spectrometer (CVAFS, Beijing Titan Instruments Co., Ltd., China). For the quality control, certified reference materials (CRMs), reagent and method blanks and sample replicates were all included in the analytical procedure. The determined concentrations of $\mathrm{Hg}$ in two sediment CRMs were $274 \pm 17.8 \mu \mathrm{g} \mathrm{kg}^{-1}$ $(n=10)$ in GBW07310 (certified value, $280 \pm 40 \mu \mathrm{g} \mathrm{kg}^{-1}$ ) and $56.3 \pm 4.0 \mu \mathrm{g} \mathrm{kg}^{-1} \quad(n=10) \quad$ in GBW07312 (certified value, $56 \pm 8 \mu \mathrm{g} \mathrm{kg}^{-1}$ ). The relative standard deviation (RSD) for triplicate analysis ranged from $3.7 \%$ to $16.9 \%$.

Statistical analysis of the obtained data was accomplished using SPSS 16.0 and Origin 8.0 software. A Kolmogorov-Smirnov test was conducted to check the normal distribution of the obtained data. One-way ANOVA, $t$-test and Pearson's correlation analysis were used to assess the significant differences and potential relationships

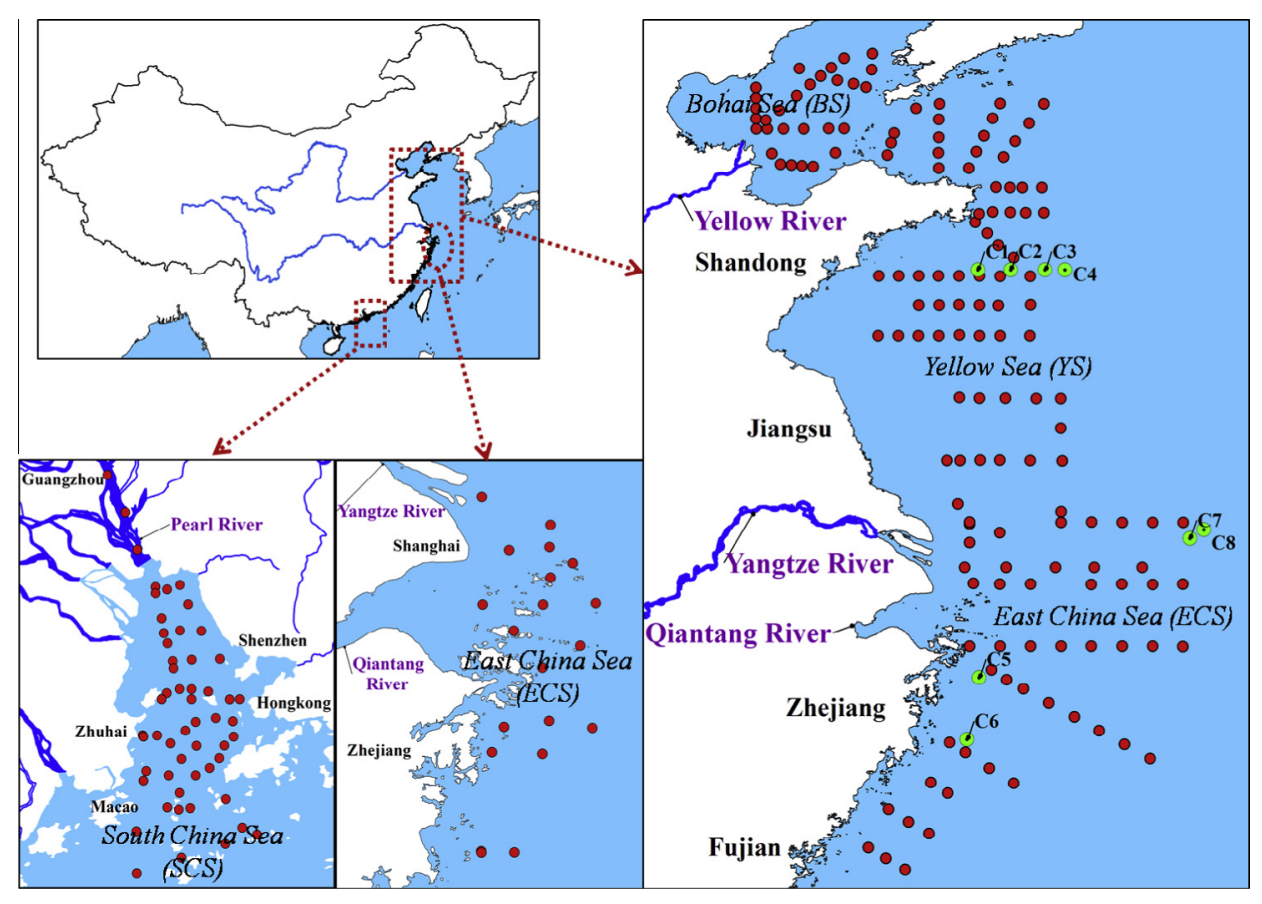

Fig. 1. Sampling sites of surface sediments and sediment cores.

Table 1

Concentrations of $\mathrm{Hg}$ in surface sediments from four China seas and eight sediment cores $\left(\mu \mathrm{g} \mathrm{kg}^{-1}\right)$.

\begin{tabular}{|c|c|c|c|c|c|c|}
\hline Sediment & Location & & $\mathrm{N}$ & Min & Max & Mean \\
\hline \multirow[t]{5}{*}{ Surface sediment } & BS & & 29 & 9.7 & 160 & 38.8 \\
\hline & YS & & 66 & 7.0 & 47.4 & 24.2 \\
\hline & ECS & & 71 & 8.2 & 84.3 & 32.8 \\
\hline & SCS & & 54 & 15.4 & 398 & 166.1 \\
\hline & Total & & 220 & 7.0 & 398 & 63.7 \\
\hline \multirow[t]{9}{*}{ Sediment cores } & YS & Core-1 & $37 \mathrm{~cm}$ & 31.2 & 168 & 58.7 \\
\hline & & Core-2 & $32 \mathrm{~cm}$ & 26.9 & 93.1 & 61.4 \\
\hline & & Core-3 & $35 \mathrm{~cm}$ & 18.9 & 85.3 & 41.2 \\
\hline & & Core-4 & $42 \mathrm{~cm}$ & 27.4 & 80.5 & 45.3 \\
\hline & ECS & Core-5 & $48 \mathrm{~cm}$ & 43.5 & 90.9 & 68.9 \\
\hline & & Core-6 & $37 \mathrm{~cm}$ & 48.5 & 83.6 & 65.1 \\
\hline & & Core-7 & $56 \mathrm{~cm}$ & 16.1 & 44.2 & 28.1 \\
\hline & & Core-8 & $57 \mathrm{~cm}$ & 14.3 & 47.9 & 26.7 \\
\hline & & Total & 344 & 14.3 & 168 & 47.4 \\
\hline
\end{tabular}

BS: Bohai Sea; YS: Yellow Sea; ECS: East China Sea; SCS: South China Sea. 
among the data. The software ArcGIS 10 was adopted to produce the contour maps by applying the Kriging method for the geospatial interpolation of the $\mathrm{Hg}$ data.

The concentrations of $\mathrm{Hg}$ in surface sediments are shown in Table 1. For all surface sediments, the concentrations of $\mathrm{Hg}$ ranged from 7.0 to $398 \mu \mathrm{g} \mathrm{kg}^{-1}$, with an average value of $63.7 \mu \mathrm{g} \mathrm{kg}^{-1}$. The concentrations of $\mathrm{Hg}$ were in the range $9.7-160 \mu \mathrm{g} \mathrm{kg}^{-1}$ (average, $38.8 \mu \mathrm{g} \mathrm{kg}^{-1}$ ) for the BS, 7.0-47.4 $\mu \mathrm{g} \mathrm{kg}^{-1}$ (average, $24.2 \mu \mathrm{g} \mathrm{kg}^{-1}$ ) for the YS, $8.2-84.3 \mu \mathrm{g} \mathrm{kg}^{-1}$ (average, $32.8 \mu \mathrm{g} \mathrm{kg}^{-1}$ ) for the ECS, and $15.4-398 \mu \mathrm{g} \mathrm{kg}^{-1}$ (average, $166 \mu \mathrm{g} \mathrm{kg}^{-1}$ ) for the SCS. The average concentrations of $\mathrm{Hg}$ in surface sediments among the four China seas followed the order: $\mathrm{SCS}>\mathrm{BS}>\mathrm{ECS}>\mathrm{YS}(P<0.01$, oneway ANOVA), with the SCS (PRE) as the most polluted region. This may be because the sampling sites in this region are located at the PRE, which is close to major cities and large industrial hubs in South China.

Fig. 2 shows the spatial distribution of $\mathrm{Hg}$ in surface sediments. In the BS, a noticeable hotspot was found at the mouth of the

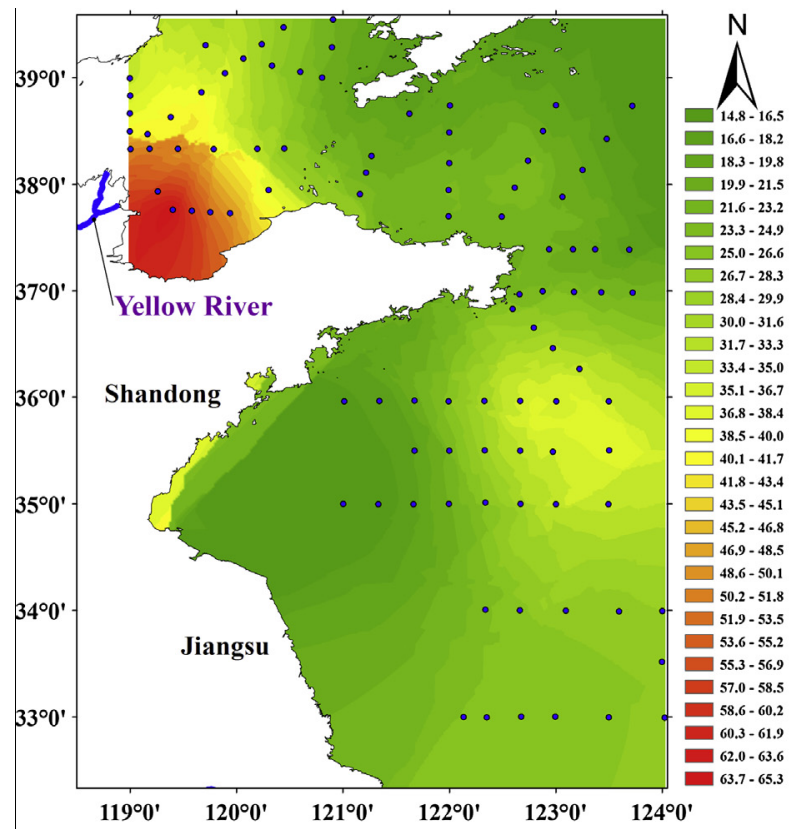

(a)

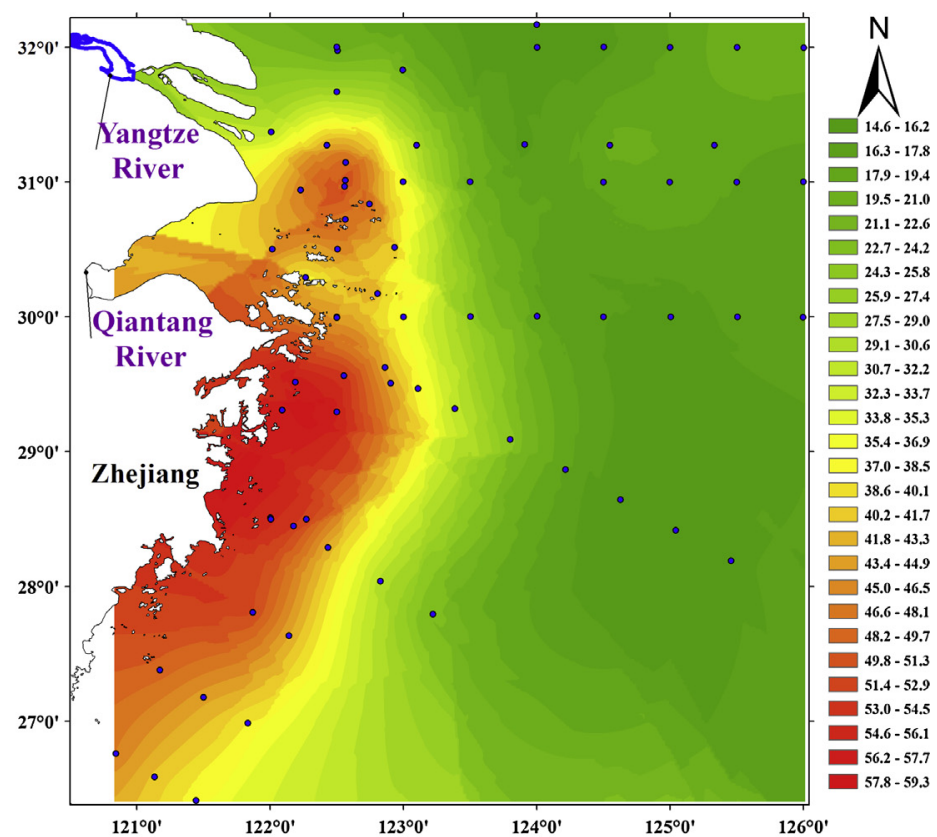

(b)

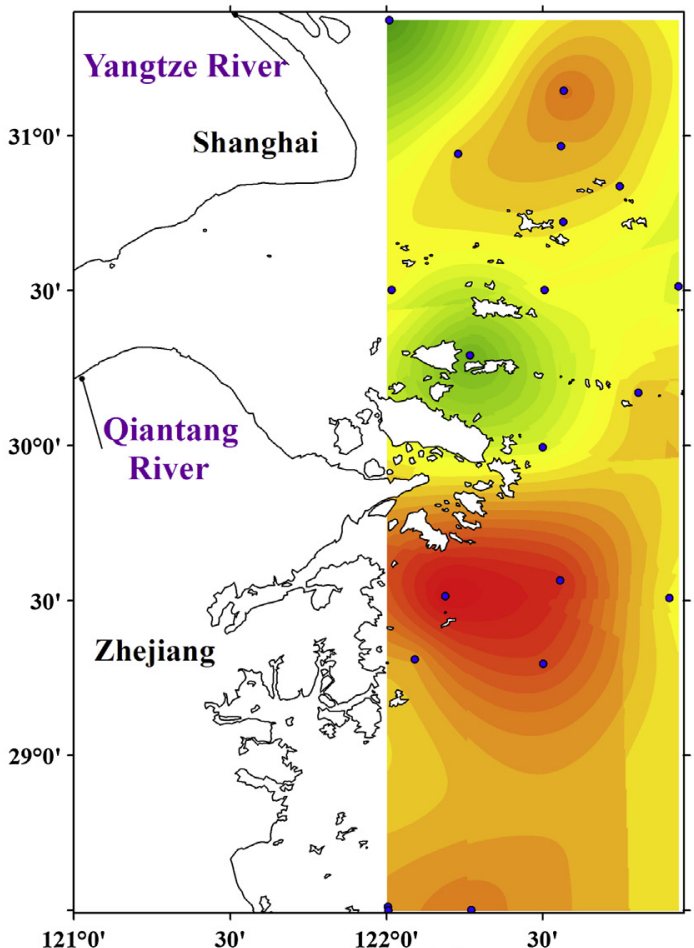

(c)

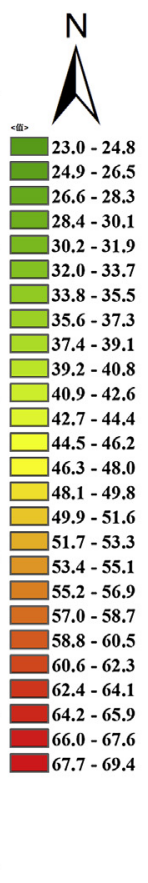

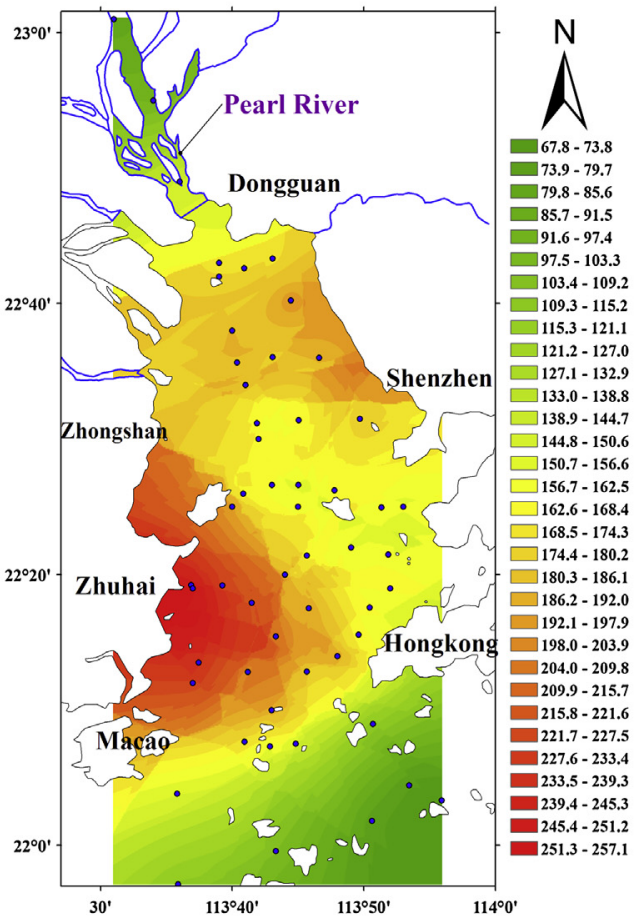

(d)

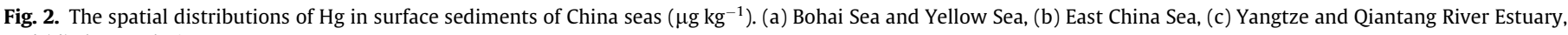
and (d) the Pearl River Estuary. 
Yellow River Estuary (YRE) (Fig. 2a), suggesting a direct influence of riverine inputs. At the YS, the $\mathrm{Hg}$ levels increased from the coastline to the central areas at both the southern and northern YS (Fig. 2a), with the highest $\mathrm{Hg}$ levels in the central mud areas. By contrast, a different distribution pattern was found in the ECS, and relatively high levels of $\mathrm{Hg}$ were located at the nearshore areas with a general offshore decreasing trend towards the outer shelf (Fig. 2b), indicating a significant influence of both riverine inputs and proximity to terrestrial-based sources along the coast. Besides, Fig. 2c shows more clearly the distribution of $\mathrm{Hg}$ along the Zhejiang-Fujian coast, and two hotspots were observed at the Yangtze and Qiantang River estuaries. However, Hg levels at the mouth of these two river estuaries were significantly lower than those at the southward areas. The same distribution pattern has also been found in our previous study in this area in 2002 (Shi et al., 2005). This is possibly caused by the high sedimentation rates at the river mouth (Huh and Su, 1999), and also a result of the nearby landbased $\mathrm{Hg}$ discharge and the circulation currents in the estuaries. Similarly, the Hg levels in sediments from the outer part of the PRE were relatively low. Two hotspots were found at the southwestern coastal regions near Zhuhai city (i.e., the key sediment deposition area in the PRE) and the northeastern coastal regions near Shenzhen (e.g., the heavily industrialized city in south China) (Fig. 2d). This also suggests a significant influence of $\mathrm{Hg}$ discharges from nearby cities and coastal circulation currents. Compared to our previous survey on the PRE (Shi et al., 2010), the highest and average concentrations of $\mathrm{Hg}$ increased from $201 \mu \mathrm{g} \mathrm{kg}^{-1}$ to $398 \mu \mathrm{g} \mathrm{kg}^{-1}$, and from $54.4 \mu \mathrm{g} \mathrm{kg}^{-1}$ to $166 \mu \mathrm{g} \mathrm{kg}^{-1}$ during the year 2002-2011, implying a significant increase of the anthropogenic emissions of $\mathrm{Hg}$ in the Pearl River Delta (PRD) region. Compared with published data on the background values of sedimentary $\mathrm{Hg}$ in the whole SCS (Zhang and Du, 2005), Hg levels in sediments of the PRE is relatively higher, indicating a strong impact of landbased anthropogenic $\mathrm{Hg}$ emissions.

Compared with published data on China seas (Table 2), the $\mathrm{Hg}$ levels in this study were in good agreement with previous results in magnitude, but slightly higher in absolute values. According to the reported background values of $\mathrm{Hg}$ in sediments (Lindqvist et al., 1984), the concentrations of $\mathrm{Hg}$ in most surface sediments in this study were still within the background range $\left(<100 \mu \mathrm{g} \mathrm{kg}^{-1}\right)$, except for most sites of the PRE in the SCS and part of the BS (YRE). Compared with other areas listed in Table 2, the concentrations of $\mathrm{Hg}$ in sediments collected in this work were lower than those from some countries in Europe, North America, Africa and Asia. This indicates that the $\mathrm{Hg}$ contamination level in sediments from the Chinese marginal seas is relatively low, except for some specific regions (the PRE in the SCS and the YRE in the BS).
The concentrations of $\mathrm{Hg}$ in the eight sediment cores are shown in Table 1 . The four cores (1-4) from the YS are all located in the central mud area of the YS, which is also a site distant from direct input sources and is characterized by cycles of deposition and resuspension under coastal currents interacting with local oceanographic conditions (Yang and Liu, 2007). The Hg levels in these four cores were quite comparable with each other, with Core- 1 in the range 31.2-168 $\mu \mathrm{g} \mathrm{kg}^{-1}$ (average, $58.7 \mu \mathrm{g} \mathrm{kg}^{-1}$ ), Core-2 in the range 26.9-93.1 $\mu \mathrm{g} \mathrm{kg}^{-1}$ (average, $61.4 \mu \mathrm{g} \mathrm{kg}^{-1}$ ), Core-3 in the range $18.9-85.3 \mu \mathrm{g} \mathrm{kg}^{-1}$ (average, $41.2 \mu \mathrm{g} \mathrm{kg}^{-1}$ ) and Core-4 in the range $27.4-80.5 \mu \mathrm{g} \mathrm{kg}^{-1}$ (average, $45.3 \mu \mathrm{g} \mathrm{kg}^{-1}$ ). Generally, the highest $\mathrm{Hg}$ values were found in the surface (recent) segments of each profile (depth, $1-5 \mathrm{~cm}$ ).

The four cores (5-8) from the ECS are located in two widely different areas of the sea. Core- 5 and Core- 6 were taken from the inner-shelf coastal mud area, a significant sink of sedimentassociated pollutants from direct river inputs and land-originated surface runoffs, while Core-7 and Core- 8 were from the centralshelf distal mud area, an ideal place for deposition of airborne contaminants transported mainly from China (Zeng et al., 2012). From Table 1 , the concentrations of $\mathrm{Hg}$ in Core-5 $\left(43.5-90.9 \mu \mathrm{g} \mathrm{kg}^{-1}\right.$, average: $68.9 \mu \mathrm{g} \mathrm{kg}^{-1}$ ) and Core-6 (48.5-83.6 $\mu \mathrm{g} \mathrm{kg}^{-1}$, average: $65.1 \mu \mathrm{g} \mathrm{kg}^{-1}$ ) were significantly higher than those in Core-7 (16.1-44.2 $\mu \mathrm{g} \mathrm{kg}^{-1}$, average: $28.1 \mu \mathrm{g} \mathrm{kg}^{-1}$ ) and Core-8 (14.3$47.9 \mu \mathrm{g} \mathrm{kg}^{-1}$, average: $\left.26.7 \mu \mathrm{g} \mathrm{kg}^{-1}\right)(P<0.01, t$-test). These clear differences of $\mathrm{Hg}$ concentration suggest that the riverine input and coastal discharge of $\mathrm{Hg}$ to the inner-shelf mud area are more significant than atmospheric input to the central-shelf mud area.

Fig. 3 shows the vertical distribution of $\mathrm{Hg}$ in the eight sediment cores. For the four cores from the YS, they all showed an obvious increasing trend, with the top layers containing the highest concentrations of $\mathrm{Hg}$. The $\mathrm{Hg}$ values in the upper segments $(0-10 \mathrm{~cm})$ of each core increased more rapidly than the lower segments. This suggests the significant increase of emissions of $\mathrm{Hg}$ in recent years in this region. The four cores from the ECS showed different variations. The $\mathrm{Hg}$ values first slightly decreased from the bottom, and then increased to the top in the upper $40 \mathrm{~cm}$. The highest $\mathrm{Hg}$ values were also found at the top layers, which could also be attributed to the rapid increasing emission of $\mathrm{Hg}$ in recent decades. The relatively high concentrations of $\mathrm{Hg}$ at the bottom layers might be resulted from the large historical deposition flux.

In order to identify the key factors influencing the distribution and transport of $\mathrm{Hg}$ in coastal sediments of China, the TOC and $\mathrm{pH}$ values in all surface sediments were analyzed. The obtained data and results of Pearson's correlation analysis are summarized in Table 3. The TOC contents were in the range $0.08-2.82 \%$ with an average of $1.35 \%$. The $\mathrm{pH}$ values ranged from 5.96 to 8.68 with

Table 2

Comparison of published concentrations of $\mathrm{Hg}$ in different marine sediments $\left(\times 10^{3} \mu \mathrm{g} \mathrm{kg}^{-1}\right)$.

\begin{tabular}{lll}
\hline Location & $\mathrm{Hg}$ & Reference \\
\hline Toulon Bay, France & $1.600(0.030-27.300)$ & Tessier et al. (2011) \\
Ionian Sea, Italy & $3.100-7.900$ & Petronio et al. (2012) \\
Mersey Estuary, UK & $0.840-5.130$ & Vane et al. (2009) \\
Guanabara Bay, Brazil & $0.870(<0.100-3.220)$ & Covelli et al. (2012) \\
Narragansett Bay, USA & $0.555(0.035-2.629)$ & Taylor et al. (2012) \\
San Jorge Bay, Chile & $0.259-1.210$ & Valdés et al. (2010) \\
Gulf of Mexico & $0.100-1.060$ & Jorge et al. (2009) \\
Biétri Bay, Ivory Coast & $0.790(0.680-0.880)$ & Coulibaly et al. (2012) \\
Mumbai Harbor, India & $0.120-0.750$ & Ram et al. (2009) \\
Sardinia, Western, Mediterranean & $<0.030-0.300$ & Schintu et al. (2009) \\
South China Sea, Malaysia & $0.100-0.130$ & Saraee et al. (2011) \\
East China Sea & $0.004-0.048$ & Fang and Chen (2010) \\
& $0.037(<0.001-0.080)$ & Shi et al. (2005) \\
Pearl River Estuary & $0.054(0.002-0.201)$ & Shi et al. (2010) \\
South China Sea & $0.061(0.005-0.148)$ & Zhang and Du (2005) \\
China Seas & $0.064(0.007-0.398)$ & This work \\
\hline
\end{tabular}


THg concentrations $\left(\mu \mathrm{g} \mathrm{kg}^{-1}, \mathrm{dw}\right)$

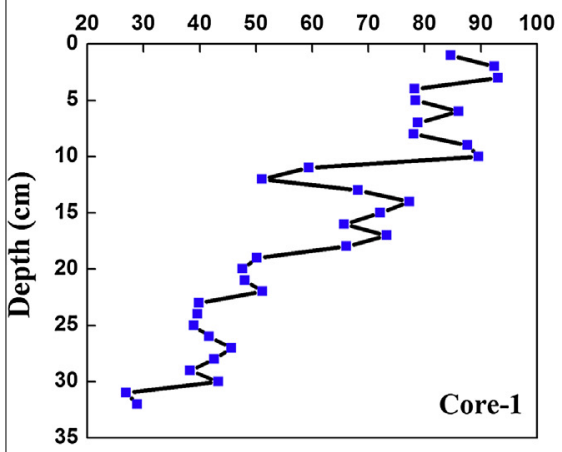

THg concentrations $\left(\mu \mathrm{g} \mathrm{kg}{ }^{-1}, \mathrm{dw}\right)$

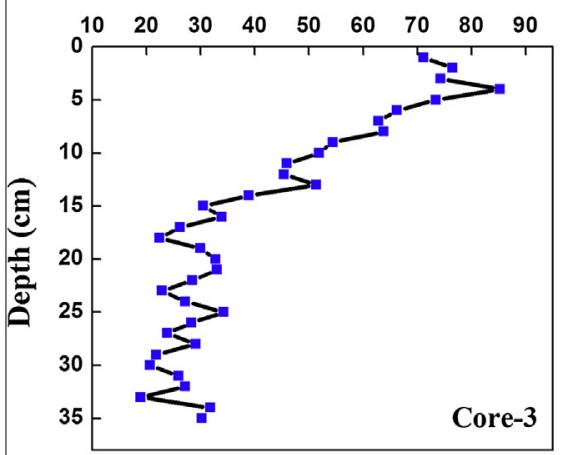

THg concentrations $\left(\mu \mathrm{g} \mathrm{kg}^{-1}, \mathrm{dw}\right)$

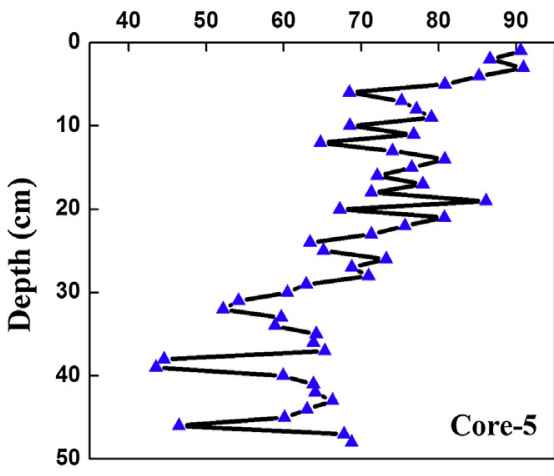

THg concentrations $\left(\mu \mathrm{g} \mathrm{kg}^{-1}, \mathrm{dw}\right)$

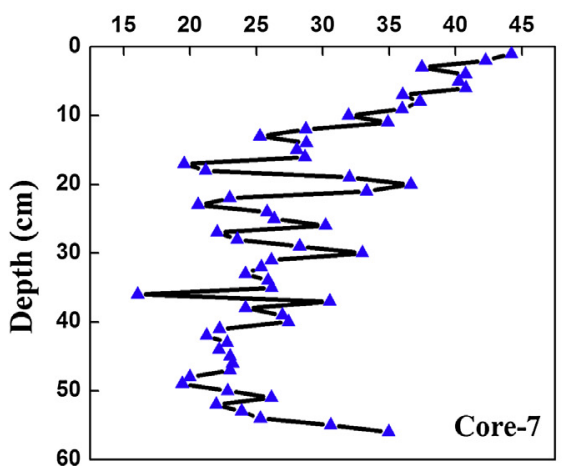

THg concentrations $\left(\mu \mathrm{g} \mathrm{kg}{ }^{-1}, \mathrm{dw}\right)$

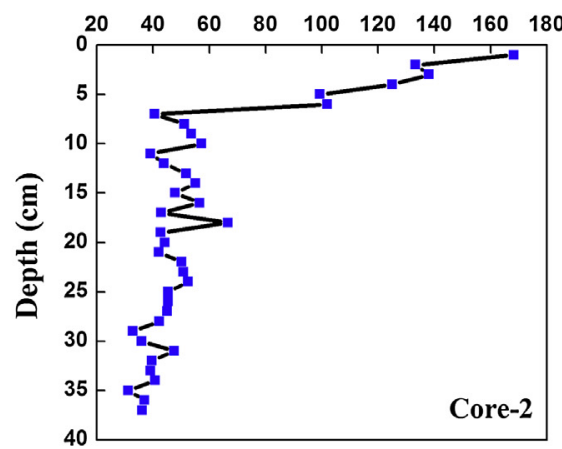

THg concentrations $\left(\mu \mathrm{g} \mathrm{kg}^{-1}, \mathrm{dw}\right)$

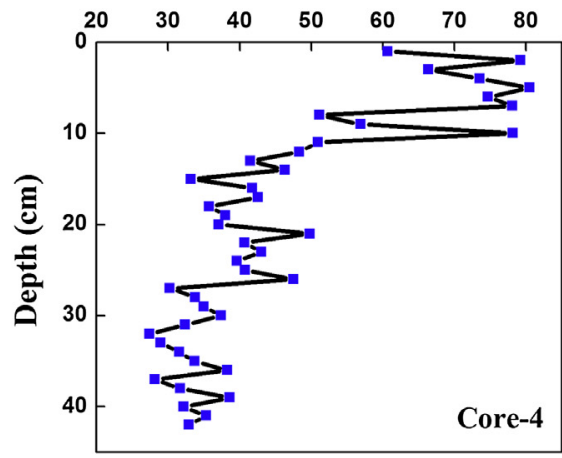

THg concentrations $\left(\mu \mathrm{g} \mathrm{kg}^{-1}, \mathrm{dw}\right)$

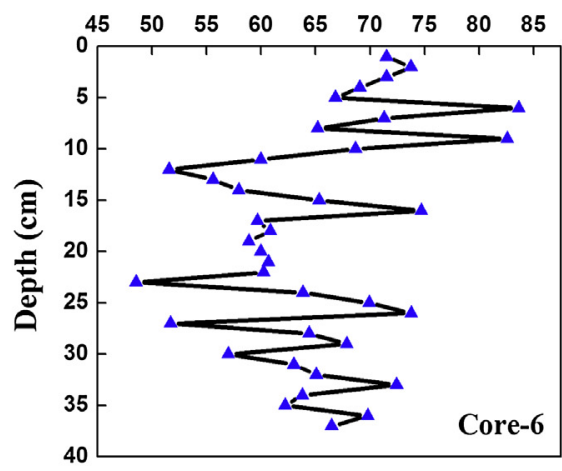

THg concentrations $\left(\mu \mathrm{g} \mathrm{kg}^{-1}, \mathrm{dw}\right)$

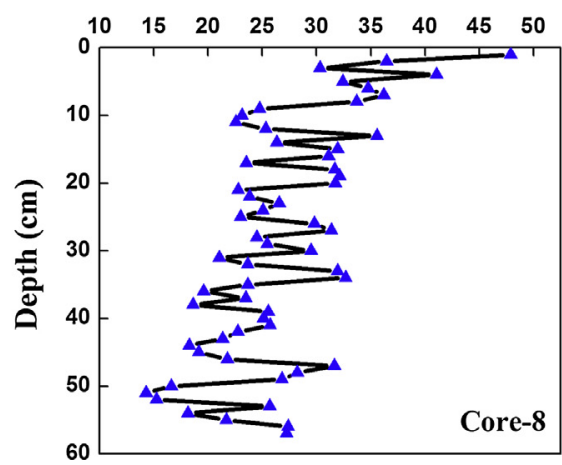

Fig. 3. The vertical distribution of $\mathrm{Hg}$ in marine sediment cores.

an average of 8.03. The correlations between $\mathrm{Hg}$ concentrations and TOC were significant in all the four China seas, while the correlations between $\mathrm{Hg}$ concentrations and $\mathrm{pH}$ were significant only in the YS and ECS. When taking all the samples together, the concentrations of $\mathrm{Hg}$ showed significant correlations with both TOC and $\mathrm{pH}$. But the influence of TOC on $\mathrm{Hg}$ concentrations was more significant than that of $\mathrm{pH}$.

Fig. 4 shows the sediment particle size distribution and general circulation system of the China seas. Ocean currents and circulation play a key role in sediment transport and deposition in the marginal 
Table 3

Correlations of $\mathrm{THg}$, TOC and $\mathrm{pH}$ values.

\begin{tabular}{|c|c|c|c|c|}
\hline Sampling sites & TOC (\%) & $\mathrm{pH}$ & $\mathrm{R}_{\mathrm{Hg}, \mathrm{TOC}}$ & $\mathrm{R}_{\mathrm{Hg}, \mathrm{pH}}$ \\
\hline Bohai Sea $(n=29)$ & $1.34(0.08-2.18)$ & $8.29(7.91-8.68)$ & $0.489^{* *}$ & -0.135 \\
\hline Yellow Sea $(n=66)$ & $1.42(0.16-2.78)$ & $8.14(7.70-8.63)$ & $0.640^{* *}$ & $-0.623^{* *}$ \\
\hline East China Sea $(n=71)$ & $1.19(0.51-2.82)$ & $8.21(7.93-8.60)$ & $0.283^{*}$ & $-0.630^{* *}$ \\
\hline South China Sea $(n=54)$ & $1.47(0.16-2.63)$ & $7.52(5.96-8.34)$ & $0.403^{* *}$ & -0.200 \\
\hline Total $(n=220)$ & $1.35(0.08-2.82)$ & $8.03(5.96-8.68)$ & $0.283^{* *}$ & $-0.679^{* *}$ \\
\hline
\end{tabular}

* Correlation is significant at the 0.05 level.

*** Correlation is significant at the 0.01 level.

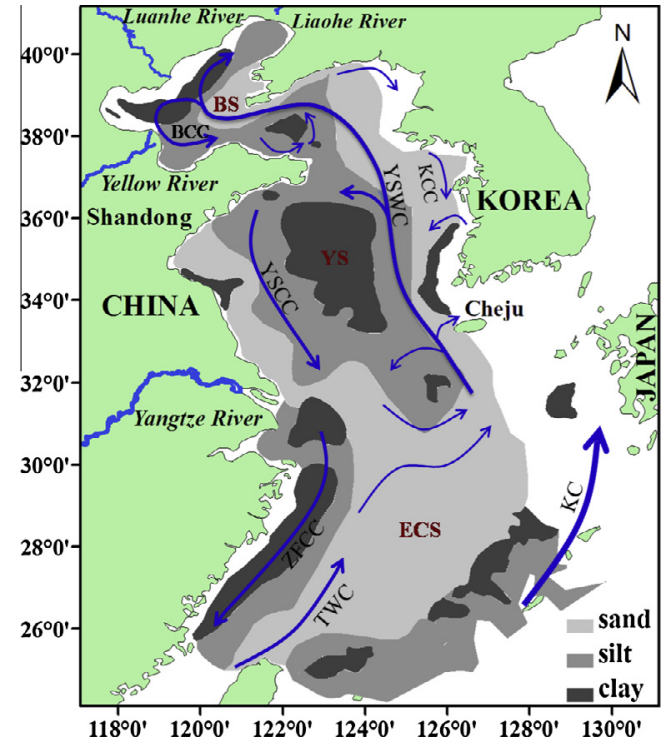

Fig. 4. Surface sediment particle size distribution and general circulation system in Chinese marginal seas (modified after Hu et al., 2011; Yang et al., 2003; Zhu et al. 2012; Guo et al., 2006). BS: Bohai Sea; YS: Yellow Sea; ECS: East China Sea; BCC: Bohai Coastal Current; YSCC: Yellow Sea Coastal Current; YSWC: Yellow Sea Warm Current; KCC: Korea Coastal Current; ZFCC: Zhejiang-Fujian Coastal Current; TWC: Taiwan Warm Current; KC: Kuroshio Current.

seas. The massive Yellow River-derived sediment flux is transported from the narrow coastal area to the offshore area during winter in the BS, but also moves eastward off the northern Shandong Peninsula driven by the Bohai Coastal Current (BCC) and then southward into the south YS driven by the Yellow Sea Coastal Current (YSCC) (Lu et al., 2011; Yang et al., 2003). The sediments in the BS are therefore mainly deposited as clay in the western part (near the YRE), silt in the central part and sand in the eastern part (Yang et al., 2003). Two general circulation patterns are reported in the YS, including a counterclockwise gyre with a northward inflow of the Yellow Sea Warm Current (YSWC) and a southward inflow of the YSCC, and a clockwise gyre with the YSWC and a southward inflow of the Korea Coastal Current (KCC). As a result, the central part of the YS is dominated by clay, while silt and sand generally blanket the eastern and western parts (Yang et al., 2003). In the ECS, a large proportion of Yangtze River-derived sediments are transported southwards along the coast driven by the Zhejiang-Fujian Coastal Current (ZFCC) and trapped in the inner shelf due to the blocking by the northward offshore Taiwan Warm Current (TWC). An elongated inner-shelf mud wedge is consequently developed from Yangtze mouth to Taiwan Strait, which is broken at the mouth of the Qiantang River (Zhu et al., 2012). Another mud area in the central ECS is formed in the southwest off Cheju Island.

Particle size distribution is another possible factor influencing the distribution of $\mathrm{Hg}$ in sediment. Normally, $\mathrm{Hg}$ could sorb more strongly to smaller particles because of their greater surface area ( $\mathrm{Lv}$ and Li, 2006). Ding et al. calculated the regressive equations between $\mathrm{Hg}$ content and particle size, and the results showed that $\mathrm{Hg}$ content was most significantly correlated with clay, the next with silt and finally with sand (Ding et al., 2009). In this study, the areas with the highest sedimentary $\mathrm{Hg}$ levels are located in muddy sediment areas. The spatial distributions of $\mathrm{Hg}$ in surface sediments (Fig. 2) corresponded well with the distribution patterns of particle size (Fig. 4), with the highest $\mathrm{Hg}$ concentrations in clay, next higher in silt and the lowest in sand. Obviously, sediment characteristics are also an important factor controlling the distribution of $\mathrm{Hg}$ in coastal sediments of China. Therefore, the mud deposits on the coastal shelves of China could be main sinks of $\mathrm{Hg}$ in sediments.

In addition, sediment particle size indirectly reflects the hydrodynamic environment. With no direct large river inputs and far away from direct sources, the YS mud area is under convergent hydrodynamic condition and is thereby more characterized by homogeneous conditions. Sedimentary $\mathrm{Hg}$ in this area may largely derive from atmospheric deposition and sedimentation. However, different from the YS, the coastal ECS is subject to more heterogeneous conditions, due to the direct continuous riverine inputs from the Yangtze River and other major coastal rivers. Comparatively, the higher $\mathrm{Hg}$ levels in the coastal ECS area suggested that riverine inputs and land-based $\mathrm{Hg}$ discharge may play more important roles than atmospheric deposition in the distribution of $\mathrm{Hg}$ in marine sediments. This indicated that sedimentary $\mathrm{Hg}$ was transported under the influence of riverine inputs and sediment characteristics, and further distributed under the influence of ocean currents and circulation.

As a whole, the $\mathrm{Hg}$ contamination in coastal sediments of China is relatively low in comparison with some coastal areas in the world. Spatial distribution showed a general offshore decreasing trend of $\mathrm{Hg}$ concentrations towards the outer continental shelf. Vertical profiles of sediment cores displayed a general increasing trend from bottom to surface layers. Coastal land-based discharges and river-derived inputs are probably the main sources of $\mathrm{Hg}$ in coastal sediments of China seas. Correlation analysis indicated influences of TOC and $\mathrm{pH}$ on the $\mathrm{Hg}$ concentration in sediments. The good agreement between $\mathrm{Hg}$ and particle size distribution suggested that the mud areas in the coastal shelves of China are major sinks of $\mathrm{Hg}$.

\section{Acknowledgments}

The work described here was supported by the National Basic Research Program of China (2013CB430004), the National Natural Science Foundation of China (41422306 and 21120102040), the Young Scientists Fund of RCEES (RCEES-QN-20130007F), and the Research Grants Council of the Hong Kong SAR Government (N_PolyU556/11).

\section{References}

Cheng, J.P., Gao, L.L., Zhao, W.C., Liu, X.J., Sakamoto, M., Wang, W.H., 2009. Mercury levels in fisherman and their household members in Zhoushan, China: impact on public health. Sci. Total Environ. 407, 2625-2630. 
Coulibaly, S., Atse, B.C., Koffi, K.M., Sylla, S., Konan, K.J., Kouassi, N.J., 2012. Seasonal accumulations of some heavy metal in water, sediment and tissues of blackchinned Tilapia Sarotherodon melanotheron from Biétri Bay in Ebrié Lagoon, Ivory Coast. Bull. Environ. Contam. Toxicol. 88, 571-576.

Covelli, S., Protopsalti, I., Acquavita, A., Sperle, M., Bonardi, M., Emili, A., 2012. Spatial variation, speciation and sedimentary records of mercury in the Guanabara Bay (Rio de Janeiro, Brazil). Cont. Shelf Res. 35, 29-42.

Ding, Z.H., Liu, J.L., Li, L.Q., Lin, H.N., Wu, H., Hu, Z.Z., 2009. Distribution and speciation of mercury in surficial sediments from main mangrove wetlands in China. Mar. Pollut. Bull. 58, 1319-1325.

Fang, T.H., Chen, R.Y., 2010. Mercury contamination and accumulation in sediments of the East China Sea. J. Environ. Sci. 22 (8), 1164-1170.

Fok, T.F., Lam, H.S., Ng, P.C., Yip, A.S.K., Sin, N.C., Chan, I.H.S., Gu, G.J.S., So, H.K., Wong, E.M.C., Lam, C.W.K., 2007. Fetal methylmercury exposure as measured by cord blood mercury concentrations in a mother-infant cohort in Hong Kong. Environ. Int. 33, 84-92.

Gu, Y.G., Wang, Z.H., Lu, S.H., Jiang, S.J., Muc, D.H., Shu, Y.H., 2012. Multivariate statistical and GIS-based approach to identify source of anthropogenic impacts on metallic elements in sediments from the mid Guangdong coasts, China. Environ. Pollut. 163, 248-255.

Guo, Z.G., Lin, T., Zhang, G., Yang, Z.S., Fang, M., 2006. High-resolution depositional records of polycyclic aromatic hydrocarbons in the central continental shelf mud of the East China Sea. Environ. Sci. Technol. 40, 5304-5311.

Hammerschmidt, C.R., Fitzgerald, W.F., 2004. Geochemical controls on the production and distribution of methylmercury in near-shore marine sediments. Environ. Sci. Technol. 38, 1487-1495.

Hu, L.M., Lin, T., Shi, X.F., Yang, Z.S., Wang, H.J., Zhang, G., Guo, Z.G., 2011. The role of shelf mud depositional process and large river inputs on the fate of organochlorine pesticides in sediments of the Yellow and East China seas. Geophys. Res. Lett. 38, L03602. http://dx.doi.org/10.1029/2010GL045723.

Huh, C.A., Su, C.C., 1999. Sedimentation dynamics in the East China Sea elucidated from ${ }^{210} \mathrm{~Pb},{ }^{137} \mathrm{Cs}$ and ${ }^{239,240} \mathrm{Pu}$. Mar. Geol. 160, 183-196.

Jiang, G.B., Shi, J.B., Feng, X.B., 2006. Mercury pollution in China. Environ. Sci. Technol. 40, 3672-3678.

Jorge, R., Federico, P., Nydia, Z., Felipe, A., Humberto, B., 2009. Mercury in biota and surficial sediments from Coatzacoalcos Estuary, Gulf of Mexico: distribution and seasonal variation. Water Air Soil Pollut. 197, 165-174.

Lindqvist, O., Jernelöv, A., Johansson, K., Rohde, H., 1984. Mercury in the Swedish Environment. Global and Local Sources. National Swedish Environmental Protection Board.

Lu, J., Qiao, F.L., Wang, X.H., Wang, Y.G., Teng, Y., Xia, C.S., 2011. A numerical study of transport dynamics and seasonal variability of the Yellow River sediment in the Bohai and Yellow Seas. Estuar. Coast. Shelf Sci. 95, 39-51.

Luo, W., Lu, Y.L., Wang, T.Y., Hu, W.Y., Jiao, W.T., Naile, J.E., Khim, J.S., Giesy, J.P. 2010. Ecological risk assessment of arsenic and metals in sediments of coastal areas of northern Bohai and Yellow Seas, China. Ambio 39, 367-375.

Lv, Y.Z., Li, B.G., 2006. Soil Science. China Agricultural Press, Beijing.

Maxson, P., 2009. Assessment of Excess Mercury in Asia, 2010-2050. Concorde East/ West Sprl, Brussels, Belgium.

Pacyna, E.G., Pacyna, J.M., Sundseth, K., Munthe, J., Kindbom, K., Wilson, S., et al., 2010. Global emission of mercury to the atmosphere from anthropogenic sources in 2005 and projections to 2020. Atmos. Environ. 44, 2478-2499.

Pan, K., Wang, W.X., 2012. Trace metal contamination in estuarine and coastal environments in China. Sci. Total Environ. 421-422, 3-16.

Petronio, B.M., Cardellicchio, N., Calace, N., Pietroletti, M., Pietrantonio, M. Caliandro, L., 2012. Spatial and temporal heavy metal concentration ( $\mathrm{Cu}, \mathrm{Pb}$, $\mathrm{Zn}, \mathrm{Hg}, \mathrm{Fe}, \mathrm{Mn}, \mathrm{Hg}$ ) in sediments of the Mar Piccolo in Taranto (Ionian Sea, Italy). Water Air Soil Pollut. 223, 863-875.
Ram, A., Rokade, M.A., Zingde, M.D., Borole, D.V., 2009. Post-depositional memory record of mercury in sediment near the effluent disposal site of a chlor-alkali plant in Thane Creek-Mumbai Harbour, India. Environ. Technol. 30, 765-783.

Saraee, K.R.E., Abdi, M.R., Naghavi, K., Saion, E., Shafaei, M.A., Solitani, N., 2011. Distribution of heavy metals in surface sediments from the South China Sea ecosystem, Malaysia. Environ. Monit. Assess. 183, 545-554.

Schintu, M., Marras, B., Maccioni, A., Puddu, D., Meloni, P., Contu, A., 2009. Monitoring of trace metals in coastal sediments from sites around Sardinia, Western Mediterranean. Mar. Pollut. Bull. 58, 1566-1587.

Selin, N.E., Jacob, D.J., Yantosca, R.M., Strode, S., Jaegle, L., Jaegle, L., Sunderland, E.M., 2008. Global 3-D land-ocean atmosphere model for mercury: present-day versus preindustrial cycles and anthropogenic enrichment factors for deposition. Glob. Biogeochem. Cycle 22, GB2011.

Shi, J.B., Liang, L.N., Yuan, C.G., He, B., Jiang, G.B., 2005. Methylmercury and total mercury in sediments collected from the East China Sea. Bull. Environ. Contam. Toxicol. 74, 980-987.

Shi, J.B., Ip, C.C.M., Zhang, G., Jiang, G.B., Li, X.D., 2010. Mercury profiles in sediments of the Pearl River Estuary and the surrounding coastal area of South China. Environ. Pollut. 158, 1974-1979.

Taylor, D.L., Linehan, J.C., Murray, D.W., Prell, W.L., 2012. Indicators of sediment and biotic mercury contamination in a southern New England estuary. Mar. Pollut. Bull. 64, 807-819.

Tessier, E., Garnier, C., Mullot, J., Lenoble, V., Arnaud, M., Raynaud, M., Mounier, S., 2011. Study of the spatial and historical distribution of sediment inorganic contamination in the Toulon bay (France). Mar. Pollut. Bull. 62, 2075-2086.

Valdés, J., Román, D., Guiñez, M., Rivera, L., Morales, T., Ávila, J., Cortés, P., 2010. Distribution and temporal variation of trace metal enrichment in surface sediments of San Jorge Bay, Chile. Environ. Monit. Assess. 167, 185-197.

Vane, C.H., Jones, D.G., Lister, T.R., 2009. Mercury contamination in surface sediments and sediment cores of the Mersey Estuary, UK. Mar. Pollut. Bull. 58, 928-946.

Wang, J., Dong, Y., Wu, J., Mu, R., Jiang, H., 2011. Coal production forecast and low carbon policies in China. Energy Policy 39, 5970-5979.

Wu, Y., Wang, S.X., Streets, D.G., Hao, J.M., Chan, M., Jiang, J.K., 2006. Trends in anthropogenic mercury emissions in China from 1995 to 2003. Environ. Sci. Technol. 40, 5312-5318.

Yan, C.Z., Li, Q.Z., Zhang, X., Li, G.X., 2010. Mobility and ecological risk assessment of heavy metals in surface sediments of Xiamen Bay and its adjacent areas, China. Environ. Earth Sci. 60, 1469-1479.

Yang, Z.S., Liu, J.P., 2007. A unique Yellow River-derived distal subaqueous delta in the Yellow Sea. Mar. Geol. 240 (1-4), 169-176. http://dx.doi.org/10.1016/ j.margeo.2007.02.008.

Yang, S.Y., Jung, H.S., Lim, D.I., Li, C.X., 2003. A review on the provenance discrimination of sediments in the Yellow Sea. Earth-Sci. Rev. 63, 93-120.

Zeng, L.X., Zhao, Z.S., Li, H.J., Wang, T., Liu, Q., Xiao, K., Du, Y.G., Wang, Y.W., Jiang, G.B., 2012. Distribution of Short Chain Chlorinated Paraffins in marine sediments of the East China Sea: influencing factors, transport and implications. Environ. Sci. Technol. 46, 9898-9906.

Zhang, Y.H., Du, J.M., 2005. Background values of pollutants in sediments of the South China Sea. Acta Oceanol. Sin. 27 (4), 161-166.

Zhou, F., Guo, H.C., Hao, Z.J., 2007. Spatial distribution of heavy metals in Hong Kong's marine sediments and their human impacts: a GIS-based chemometric approach. Mar. Pollut. Bull. 54, 1372-1384.

Zhu, M.X., Hao, X.C., Shi, X.N., Yang, G.P., Li, T., 2012. Speciation and spatial distribution of solid-phase iron in surface sediments of the East China Sea continental shelf. Appl. Geochem. 27 (4), 892-905. 